\title{
Development and Management Perspective of Small and Medium Enterprises in Kosovo
}

\author{
Phd. (c) Remzi Ahmeti
}

KRM. Uniteti Sh.a. Mitrovicë

Phd. (c) Rifat Hoxha

Prof. Ass. Dr. Hamdi Hoti

Doi:10.5901/ajis.2015.v4n2p467

Faculty of Economics, University "Ukshin Hoti” Prizren

Abstract

The paper presents the development and the future of small and medium enterprises in Kosovo with particular emphasis on the management aspect. The paper highlighted the diagnosis of the current situation of SMEs, identify problems, obstacles and barriers that are suffocate the development of their activities, identifying needs and requirements of the community to improve the situation of SMEs, the advancement of processes development and the development of positive trends in strategic terms. The formation and development of SMEs has contributed to employment growth and market device with different products and services. Employment in private enterprises is increasing where structural changes can be observed within the enterprises, which are expressed through a decline in the number of commercial enterprises and increasing the participation of manufacturing enterprises. Issues addressed in this paper are how we can improve the development of SMEs as an obstacle factors influencing his process? how can you help young entrepreneurs?, how can we increase the number of employees, innovation, improvement of trade balance? And how to encourage local production and increase overall performance? Finalization of the paper will enable adequate addressing of the difficulties and problems faced by enterprises in Kosovo and enables the extraction of the necessary recommendations for the next steps of development of SMEs, creating incentives and support for economic activities that develop them in order to support economic growth and employment in general in future generations.

Keywords: SME-s, Development, Economy, Business, Competition

\section{Management of Small and Medium Enterprises in Kosovo}

Management is a process of conscious orientation of human activities towards the achievement of the goal. Management is the process of forming and maintaining the environment in which individuals, working together, realize goals previously set. Management of enterprise depends directly on the forms of organization of the firm (Industry).

The success of the enterprise manager is important, it has a key role in the work process, uniting and coordinating scarce resources to achieve the objectives of the enterprise, to accept the risk, take decisions in a dynamic environment where intersect and influence on a range of wide economic factors, social and technical. The role of the manager in the enterprise is to ensure that the organization is implementing the basic goals, and efficient production of products and services, to determine and maintain the stability of operations of the organization, to develop the strategy and adopt the organization in a way check against environmental changes as the official authority that manages the organizational system.

Usefulness of the organization and the acceptance by consumers of products or services that the enterprise depends on how business manages its basic operations such as planning, organization, management, staff and control that make up a process that fulfills the work activities in enterprise.

The activities necessary to carry out the work and create quality expected by customers.

\section{Understanding the Role of Small and Medium Enterprises in the Country's Economy}

SMEs have very long history, and their development is marked by their extension and occasional stagnation. The rapid development of SMEs arrives in the early 70s of the twentieth century. Innovation is that from then SME-s successfully face the challenges of competition and globalization (Small Busines and Medium Importance of SMEs in market economy).

Trying to make a reflection on the role and importance those SMEs in the domestic economy, we arrive at the 
general conclusion that primarily SME-s is gaining more and more importance in the market economy.

Their importance is reflected every time more job opening, a powerful reason to solve a vital problem as is unemployment in the country. The role of SMEs is seen as irreplaceable support point that based on this can be strengthened areas of innovation, and then the improvement of economic structures of the country, hence the improved offers in the market, and development of entrepreneurship.

It is worth mentioning that the latter is given great importance and sometimes we have heard numerous projects from foreign organizations that are funding and strongly support the field of entrepreneurship, and is supporting our local businesses in an effort to increase and the overall development of the economy.

SMEs today are oriented towards the local market and the role of the biggest ever in international exchanges. In economic literature developed countries today are distinguished four contributing factors of SMEs in the market economy.

$1 \rightarrow$ Contributions to the processes of technological change,

$2 \rightarrow$ Contribution in bringing healthy competition,

$3 \rightarrow$ Creation of new jobs,

$4 \rightarrow$ Rich offer of local products.

It is considered that about $60-70 \%$ of new jobs in the OECD (Organization for Economic Cooperation and Development) developed of the world are based on the development and establishment of SMEs.

Impacts on the growing importance of SMEs come mainly from the increased share of the service sector, manufacturing and construction sectors.

SMEs today are demonstrating a high degree of innovation, flexibility and adaptation to changes that occur in the environment. Economies that have large percentage of SMEs come easier and less affected by the recession. Greater presence of small businesses will affect the direction of the company in the local market, a reduction in demand for capital and consulting services do not use the markets in which we can benefit from the presence of economies of scale.

Currently, there is an unfavorable environment, and the absence of creative and entrepreneurial culture, today the economy is changing, providing opportunities for new businesses.

The private sector has a direct impact in the field of technology, in bringing healthy competition, opening new jobs and offer rich product in local markets. According to some research from the current situation in Kosovo and in the region we can say that the level of SMEs, despite the continuous development is facing a number of barriers that have to do with the lack of legal environment, unfair competition and lack access to external sources of financing (Financial of SME development draft research report, 2010).

\section{SME Development in Kosovo}

SMEs are a very important component of economic development of Kosovo. They are considerable source employment and help to stimulate innovation, economic dynamism and competitiveness.

SMEs in Kosovo have begun to be established prior to 1989, but more pronounced growth of their establishment have achieved in the years 1990-1993.

After this period, their foundation begins to decline significantly. The establishment of these enterprises is not the result of creating the necessary conditions in Kosovo, but were years when people dismissed from work as a solution to the situation at that time to survive they are forced to set up their enterprises as an alternative to its own employment and family.

More than 38\% of SMEs have been established until 1990 so that after this year the dynamics of the SME foundation comes constantly dropping to $0.7 \%$ in 1998 .

The causes of the decline can be explained by the political and security situation in these years, as well as sample survey which has been focused on researching the characteristics of the same enterprise development (sample) since 1997 (Riinvest, 2013).

Using legal possibilities created these individual entrepreneurs make their transformation activity in private enterprise. These resources, although without enough were important for the development of the initiative for the establishment of private enterprises.

After the war, it has manifested a temporary revival and recording of many business entities. In the mid founders there is a high level of professional training with higher education, since most of them (58\%) have completed at least high school, and more than (98\%) have completed high school.

Gender structure of founders dominate men (96.4\%), while women make up only $3.6 \%$.Statistics from that time as the establishment of enterprises by women have undergone minor changes in percentage growth, still have a strong 
support with the empowerment of women in the establishment of businesses.

In 2000 , in a third of cases the management of the company as a whole is divided by function property.

The role of the owner as the manager is further expressed to micro enterprises (45\%), while this role is expressed less to small enterprises (33\%) and no less to medium enterprises (22.4\%).

Almost half of medium-sized enterprises run by the manager and owner together (47\%).Most enterprises (73.8\%) have been established by a founder, (16.1\%) of them from the two founders, while $10.1 \%$ have three more bodies, which means that the greatest percentage of businesses in Kosovo is made up of small businesses and to medium and a small percentage of them belong to large businesses (corporate).

By 2004 he had constant increase of SMEs, the statistics for this year were $75.2 \%$ but in 2005 we see a decrease in individual enterprises and $3.2 \%$. Also to businesses organized as limited liability companies notice a significant decrease of $8.7 \%$ or by $20 \%$ in 2004 to $11.3 \%$ in 2005 .

But after this year the economy has continued at the rate of 3-5\% growth for nearly a decade.

There are indications that in recent years the most important activity of the SME sector is becoming production while the share of trade in the overall structure of enterprises is falling, while manufacturing and services are increasing their participation.

\section{Review of the Current Situation of SMEs and Not Obstacles to Development}

Small and medium enterprises are the promoters of the creation of new jobs; they are just driving force of economic prosperity, greater hopes of youth as we know that SMEs employ the largest number of young people in Kosovo. Operation of SMEs plays an important role in the overall scheme of economic development as they account for $65 \%$ of jobs in the Republic of Kosovo.

The role of SMEs is observed through the influence and contribution to employment and to raising domestic product (GDP).Despite this, Kosovo is still in transition phase, where entrepreneurs and creation of small businesses are expected to play important role in the path to modern market economy free, fair therefore economic development and growth ( (Minystri of Trade and Industry, 2015)).

Lack of innovative businesses with fast growing creative entrepreneurship culture in the workplace as in Western developed economies lead Kosovo into a lack of investment and research development.

More than $50 \%$ of small and medium enterprises in Kosovo are oriented in the trade sector, which is characterized by small investments and only $10 \%$ of them operate in the manufacturing sector.

This is mainly due to the fact that SMEs in Kosovo are not competitive at the international level and as such are not directed towards.

Today SMEs are weak exporting products, and are not competitive which prevent a further contribution to raising domestic product, the creation of jobs and economic growth in general. The difficulties of our enterprise products are trying to penetrate the market, the best shows regarding the necessity that Kosovo SMEs take reforms in management, marketing and a more decentralized system of enterprise.

They need greater regional expansion, and this should follow the rising level of education and training. Moreover also need to work more in increasing the participation of Kosovo products in the markets of neighboring countries and certainly also in the markets of other countries of the European Union (EU).

Due to the relatively low level of integration of Kosovo into the global economy and lax fiscal policy, the economy has been significantly protected from the global economic crisis.

Economic growth has largely been driven by trading costs, while external trade balance has remained high.

Based on the report of the World Bank, a major part of economic progress it has recently been based on donor aid and remittances, which cannot be the basis for sustainable economic strategy.

In terms of policy development, the report "SME Policy Index of 2009" shows that for various reasons, Kosovo is still at the stage of completing the basic institutional requirements, legal and regulatory frameworks dealing with SME policy (Minystri of trade and Industry, 2015).

From research that have been developed with enterprises, micro, small and medium enterprises, specifically referring to research of 800 SMEs which were realized in late 2010 and early 2011 show that the main obstacles of development SMEs related with the creation of jobs are as follows:

$\square$ Access to finance (credits, interest, timeliness);

$\square$ General economic situation;

$\square$ Electricity energy; 
$\square$ Foreign trade circumstances (Finance, 2015)

SMEs in Kosovo suffer from a variety of internal and external such as (Industry, Starting businesses and services to support initial businesses in Kosovo, 2015).

Protected market- The local SMEs operating in a protected market are the fact of a very small in volume, with higher transport and import costs, and as an outcome of this is outside the focus of international companies.

This results in prices that are generally high by EU standards. Kosovo producers, with low wage costs are able to achieve better profit margin despite generally showed low levels of competence, efficiency and effectiveness. The fact that some companies can generate a profit despite appropriate production facilities and organization ineffective, make companies believe that they are competitive, while the main reason for their competition "perceived" is the lack of international competitiveness.

Low price perception in Kosovo - where the majority of SMEs in Kosovo believe that only low priced goods have sales, despite evidence to the contrary on the shelves of the shop. Most of their products are weak, conservative with poor packaging and promotion.

The price is understood by everyone and is easy to change and the quality of packaging and distribution of products is much more complex.

The family management - the biggest problem in most local companies is customary to include family members in top management. Underlining the lack of confidence on other people, resulting in the employment of the family member in managerial positions, despite of their professional qualifications.

SMEs will not be able to develop competitiveness or increase if the manager do not employ because of their qualifications, skills and experience.

Lack of focus - there is a tendency among SMEs in Kosovo, to achieve a state of relative success to begin the process of developing business areas in which management has little or no knowledge and experience.

Lack of strategic perspective - In Kosovo there is a tendency among owners and managers of SMEs to develop business without plans and strategic thinking that as consequence they arising in market without proper perceived and considered analysis of the trends and characteristics of specific segmentation market, existing competition or reflecting on their internal resources and competencies in relation to the new business area.

Customs duties on imported basic materials- For small countries with small domestic markets, export represents the opportunity for almost unlimited growth. SMEs are needed to import unprocessed material to produce their final product.

In Kosovo today, reported by the managers interviewed, companies are subject to $10 \%$ customs duties on imported raw materials that are not recoverable when the final product is exported.

Training- Most owners and managers of enterprises in Kosovo do not have a formal education on the management of a company.

The need for education and training is recognized but there reluctance to participate and invest in training activities. Kosovo does not believe in formal training as an important way to develop competition.

In the future, interventions should be directed towards supporting individual companies and training must be combined with independent consultancy.

\section{Government Program for the Development of Small and Medium Enterprise}

Governing Program 2011-2014 (Kosovo Government, 2011b), the Government establish strategic objectives for the improvement and development sector of industry and SMEs.

Strategies are designed to provide medium and long term framework for the development of these sectors.

The government's program is based on four pillars:

$1 \rightarrow$ Sustainable economic development;

$2 \rightarrow$ Good governance and strengthening the study of law;

$3 \rightarrow$ Human capital development;

$4 \rightarrow$ Social Welfare.

The importance of innovation is highlighted across throughout the document. Specific measures to support SMEs and private business sectors include the presentation of a development scheme to support the pre incubation periods, incubation and post-incubation in order to increase competitiveness and innovation of SMEs.

The program includes innovation as the driver of economic growth and stresses the importance of promoting innovation in the overall economy (Program, 2015) 
Kosovo institutions have intensively continued speed on simplifying national legislation in the field of industrial policy and SMEs.

It adopted the Law on Economic Zones, which clearly defines the role of government and the municipalities in the creation of free economic zones. Kosovo has made progress in the ranking of "Doing Business" of the World Bank. In March 2013, the Government of Kosovo approved the Strategy for the Development of the Private Sector from 2013 to 2017 in order to develop competitive private sector.

Strategy identifies strategic industrial sectors that have to take account relevant Kosovo institutions, as well as priorities in the legal aspects of the approximation of national legislation with the EU, in particular in the area of free movement of commodities and trade. Despite the above achievements, there remain a number of challenges that Kosovo institutions should address effective mechanisms for their elimination.

Development of the institutional framework remains part of preparing local authorities for the implementation of SME policies, with particular emphasis implementation of the strategy for the development of the private sector, as well as an action plan which should be monitored more effectively.

In order to addressing the challenges evident the aforementioned, MTI will make development of enterprises categorized systems. This will be achieved through improvement of the existing data on SMEs and their classification and categorized on a sectored basis.

MTI together with municipalities will continue to further reduce barriers to doing business, with a focus on barriers that are within the competence of municipalities. Enabling online business registration will be an incentive indicator for young entrepreneurs to facilitate the procedures. Within the administrative advances in this direction will be the unification of the number of businesses that will serve as accurate statistics for the development of other planning ahead.

With the aim of improving access to finance for private sector enterprises in general and MTI will realize the applying for membership in EU development institutions and other donors, with the aim of creating financial instruments to facilitate SME access to finance.

At the same time it will work to increase funds dedicated to the credit guarantee scheme, as well as increased funding for SME subsidies.

\section{Business Impact of Small and Medium Enterprises in the Country's Development}

SMEs are businesses that consist $99 \%$ of the country's economic development, and is considered as one of the basic sectors in the creation of a sustainable economic budget of the Republic of Kosovo.

SME development is an essential element of economic development in the Republic of Kosovo and to contribute to increasing employment and existence, economic and social welfare of families in the country.

But to create a family business many people reluctant for many reasons, first they do not have education, do not have the experience and the money simply afraid that may fail, while others not familiar with the idea that we cannot change life their own established business therefore lack the courage, while others left without work and have no income with which to survive, opening a personal business an economic necessity and a challenging thing because before they can presented real difficulties and risks.

But the question is whether they have institutions of Republic of Kosovo, respectively, including the Government, a strategic document that will assist in the development of the country in economic terms?

Government of the Republic of Kosovo has adopted a strategic document known as Vision 2014, which sets new ambitious goals in order of growth of 7-8\%, which would reduce unemployment by 8-10\%, while SME Strategy sets out clear guidelines on how Kosovo that aims to support the private sector in increasing its competitiveness.

SMEs operating in the all parts of the economy, where it is worth noting the service sector, retail, and all the areas where economic activity is extended.

To develop a healthy economy, and sustainable development that opens up new places of work, of course, that the country needs for financial support from the government and major development projects that will assist the SMEs in terms of overall development to buy new technology and advanced and opening new stores with different economic activities to employ more people, depending on the needs and possess the skills, which will result in the development and establishment of perspective in the local economy.

It is important for the government to allocate sufficient funds for businesses that have good performance but also make efforts to motivate new businesses and especially for presentations of best business plans in an effort to open new businesses which claim that these products are new businesses ensure new work places because an essential element in our country is the issue of employment of youth and middle layers of the active population as initiatives that are seen 
so far is making efforts to support and strengthen the private sector because the private sector is a system that functions more as compared with the social.

SMEs are a promoter of economic development, they represent an important source of employment for the population and they are the main pillar of the economic development.

\section{Conclusions and Recommendations}

\subsection{Conclusions}

Lack of proper legal infrastructure that regulates the manner of establishment and operation of SMEs in Kosovo, the absence of major economic policies that support the development of the private sector and in particular SMEs are further impedes smooth functioning and the normal development SMEs, some of which with more difficulty and risk investments have survived since the postwar period.

Do not definitive definition of competencies in certain areas of economic activity, as in the area of fiscal policy and administration in the field of monetary and credit policy, and in area of exchange with the world and payments with the world, are creating problems and obstacles which later are hesitating reflect developing private economy, even total collapse of some SMEs.

Kosovo's government has repeatedly stated and has made efforts to adopt numerous programs, to achieve during their time are in power governing, but not every time these plans reached the target and goals realized, in one of the governmental programs of the year 2011-2014, defining the objectives and strategic framework for the work ahead. Economic program based on the principles of a market economy with free competition.

This vision will be achieved through market mechanisms with the state institutions will aid in regulating particular sector and to ensure the social welfare of citizens.

Identification and exploitation of comparative advantages of the country, economic subjects and human resources, as well as optimization of the use of these resources are substantial elements for the welfare and economic prosperity.

\subsection{Recommendations}

To have larger initiatives of the government for financing of SMEs by including relations with donors and other entities this will result in alternatives to finance SMEs and reducing the disproportion between supply and demand.

Creating a strategy that aims of the improvement the management of investments in key sectors, as well as of government's effort to stimulate the increasing competition through banks and non bank financial institutions, which enables further improvement of credit and financing terms.

To create the opportunities for promotion and export support activities, including the possibility of SMEs to cooperate with foreign partners through joint investments. Development of the legal and regulatory frame work in the most transparently manner, as well as including big opportunities for participation in the business community along. Having further developments programs for credit guarantees to the Kosovo market, which need legal regulation, information and training

Strengthening cooperation between the business community and the government as well as promoting sufficient investment possibilities in the SME sector.

Through support and further development of SMEs to contribute to employment and economic development.

\section{References}

Finance, M. 0. (2015, April 15). Strategy for private sector development 2013-2017. 2013-2017 , p. 9.

(2010). Financial of SME development draft research report. Prishtina.

Industry, M. 0. Research SMEs . Prishtina: Ministry of Trade and Industry.

Industry, M. 0. (2015, April 17). Starting businesses and services to support initial businesses in Kosovo. Starting businesses and services to support initial businesses in Kosovo , pp. 32-34.

Program, T. K. (2015, April 10). Evaluation of Innovative System in Kosovo. p. 44.

Riinvest. (2013). The dynamics of development of SMEs in Kosovo. Prishtina: Riinvest.

Small Business and Medium Importance of SMEs in market economy . Prishtina.

Small Business and Medium: Muhamet Mustafa, Enver KUTLLOFCl, Petrit Gashi, Besmik Krasniqi, Pristina 2006

HOTI Hamdi, MUSTAFA Agron, BERISHA Bekim: "The impact of SMEs in Economics" Internacional Conference Research and Education-Universityof Shkodra Luigj Gurakuqi, May 2013.

HOTI, Hamdi: The role and importance of small and middle enterprisein Kosovo, Publication, international scientific journal Diskutime, Tetovë, September 2013. 